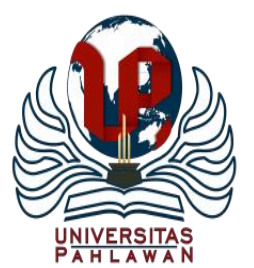

Jurnal Basicedu Volume 5 Nomor 1 Tahun 2021 Halaman 178-187

JURNAL BASICEDU

Research \& Learning in Elementary Education

https://jbasic.org/index.php/basicedu

\title{
Eksplorasi Sistem Pelaksanaan Evaluasi Pembelajaran di Sekolah pada Masa Pandemi Covid-19 di Bima
}

\author{
Muh. Fitrah ${ }^{1}$, Ruslan ${ }^{2}$ \\ IAI Muhammadiyah Bima, Indonesia, ${ }^{1,2}$ \\ Email: fitrahmath@gmail.com ${ }^{1} \underline{\text { ruslanamarizqi@gmail.com }}^{2}$
}

\begin{abstract}
Abstrak
Penelitian ini secara umum bertujuan untuk mengeksplorasi sistem pelaksanaan evaluasi pembelajaran di sekolah beserta problem yang dihadapi selama pandemik Covid-19. Jenis penelitian yang digunakan ialah kualitatif sifat eksploratif yang lakukan di SD/MI, SMP/MTs, dan SMA/MA/SMK di Kota dan Kabupaten Bima. Sumber data penelitian diperoleh dari guru mata pelajaran sebanyak 30 orang responden dengan menggunakan metode wawancara secara langsung dan dokumentasi. Sedangkan instrumen utamanya ialah peneliti yang dilengkapi menggunakan pedoman wawancara dan handphone. Bentuk analisa data penelitian ialah kualitatif bersifat deskriptif. Hasil penelitian menunjukkan bahwa pelaksanaan evaluasi pembelajaran di sekolah selama pandemi Covid-19 kurang efektif dan tidak maksimal dilakukan terutama aspek kognitif, afektif, dan psikomotorik. Guru hanya mampu menggunakan aplikasi WhatsApp sebagai sarana utama proses evaluasi dan bahkan ada pula menggunakan aplikasi Zoom Meeting. Hal ini terbukti bahwa guru hanya menyimpulkan dari hasil pengerjaan soal yang telah diberikan semata tanpa memastikan prosesnya. Terlepas dari hal demikian, guru mengalami kendala dalam pelaksanaan evaluasi ini, antara lain: guru kebingungan memilih instrumen yang akan digunakan, skill guru, orang tua, dan siswa dalam teknologi rendah, partisipasi siswa lemah, terbatasnya siswa dan orang memiliki handphone, jaringan lemah dan kuota terbatas dan menunggu bantuan pemerintah.
\end{abstract}

Kata kunci: evaluasi, pembelajaran, pandemik, covid-19

\section{Abstract}

This research generally aims to explore the system of implementing learning evaluation in schools along with the problems faced during the Covid-19 pandemic. The types of research used are qualitatively explorative properties conducted in elementary/MI, junior high schools, and high schools/MA/vocational schools in Bima city and regency. The research data source was obtained from the teacher subjects as many as 30 respondents using live interview methods and documentation. While the main instrument is researchers who are equipped using interview and mobile phone guidelines. The form of analysis of research data is qualitatively descriptive. The results showed that the implementation of learning evaluations in schools during the Covid-19 pandemic was less effective and not maximal, especially cognitive, affective, and psychomotor aspects. Teachers are only able to use WhatsApp application as the main means of evaluation process and there is even using Zoom Meeting application. This is evident that the teacher only infers from the results of the work of the question that has been given solely without ensuring the process. Despite this, teachers are experiencing problems in the implementation of this evaluation, among others: teachers are confused choosing the instruments to use, the skills of teachers, parents, and students in low technology, student participation is weak, students and people have mobile phones, weak networks and limited quotas and waiting for government assistance.

Keywords: evalution, learning, pandemic, covid-19

Copyright (c) 2021 Muh. Fitrah, Ruslan

$\triangle$ Corresponding author :

Address : Jalan Anggrek No. 16 Ranggo Na'E Kota Bima

Email : fitrahmath@gmail.com

ISSN 2580-3735 (Media Cetak)

Phone : 082340777348

DOI : https://doi.org/10.31004/basicedu.v5i1.639 
179 Eksplorasi Sistem Pelaksanaan Evaluasi Pembelajaran di Sekolah pada Masa Pandemi Covid-19 di Bima - Muh. Fitrah, Ruslan

DOI: https://doi.org/10.31004/basicedu.v5i1.639

\section{PENDAHULUAN}

Pandemi Covid-19 di Indonesia memberikan dampak buruk untuk tatanan kehidupan, dan salah satunya ialah domain pendidikan. Bahkan ada dampak positifnya dalam pendidikan yakni dapat memotivasi untuk melewati masa-masa sulit agar tetap fokus meraih tujuan pendidikan Indonesia yang lebih maju (Suteki, 2020). Covid-19 ialah penyakit yang baru ditemukan di Wuhan, Tiongkok, bulan Desember 2019. Pandemi ini pula bagaikan memberikan jalan baru kepada sebuah transformasi baru dalam kehidupan (Wekke Ismail, 2020).

Bentuk dan tindak lanjut pemerintah yakni Mendikbud mengeluarkan kebijakan melalui Surat Edaran Nomor 4 Tahun 2020 tentang pelaksanaan pendidikan masa darurat penyebaran Corona Virus Desease 2019 (Covid-19) untuk bekerja dari rumah dan belajar dari rumah (belajar secara daring) (Kemdikbud, 2020). Artinya setiap proses belajar mengajar ditiadakan dulu dalam masa covid-19. Hal ini salah satu jalan untuk menahan penyebaran pendemi Covid-19 di seluruh dunia yang berdampak pada jutaan pelajar (Syah, 2020; Nurkholis, 2020).

Namun, kebijakan tersebut berefek pada proses pendidikan untuk siswa, guru, dan orang tua (Purwanto et al., 2020; Siahaan, 2020), dan salah satu dasar masalahnya ada pada ketidaksiapan fasilitas (Arifa, 2020), dan minimnya pengetahuan (Ahmad et al., 2020), serta minimnya pengalaman guru (Syah, 2020; Indrawati, 2020). Oleh karena demikian dibutuhkan waktu beradaptasi dan menyebabkan keterlambatan proses pembelajaran, serta perbedaan kondisi wilayah yang belum ke semuanya dapat dijangkau internet secara menyeluruh (Mustafa, 2020; Sari et al., 2020).

Pembelajaran daring dilakukan sebagai pilihan strategis dalam memutus penyebaran wabah Covid-19 di dunia pendidikan, karena daring esensinya ialah dilakukan tanpa bertemu secara langsung. Hal ini relevan dengan pencegahan penyebaran covid-19 melalui social distancing dan fisical distancing (GTPP Covid-19, 2020). Pemanfaatan sistem pembelajaran daring ialah usaha yang dapat dilakukan untuk mengatasi problem siswa untuk mengakses materi pelajaran dan saling berkomunikasi, berdiskusi secara online.

Sistem pembelajaran daring telah diterapkan di beberapa sekolah, mulai dari PAUD sampai pada perguruan tinggi untuk tetap memberikan pelayanan di dunia pendidikan dan bentuk aplikasi dari Revolusi Industri 4.0 yang menitikberatkan pembelajaran berbasis pada teknologi. Beragam platform yang dapat dipilih secara gratis oleh guru untuk keberlangsungan proses belajar secara daring, seperti Google Classroom, WhatsApp (Abidah et al., 2020) dan yang dapat mengirimkan pesan berupa teks, gambar, video dan file dalam bentuk word dan $p d f$ (Firman et al., 2020; Yulianto Yulianto, 2020).

Dikarenakan proses belajar mengajar secara daring tentu guru dan sekolah mutlak melakukan evaluasi, pengukuran dan penilaian. Sebab, tanpa proses evaluasi maka arah tak akan jelas baik untuk guru, siswa, sekolah, dan orang tua. Terlepas dari konteks itu, proses pembelajaran daring pun perlu menguatkan aspek capaian siswa. 
180 Eksplorasi Sistem Pelaksanaan Evaluasi Pembelajaran di Sekolah pada Masa Pandemi Covid-19 di Bima - Muh. Fitrah, Ruslan

DOI: https://doi.org/10.31004/basicedu.v5i1.639

Pelaksanaan evaluasi ialah inti dari pelaksanaan pendidikan dan suatu keharusan untuk dilakukan serta menjadi catatan penting guna memetakan capaian siswa pada proses pembelajaran dan memperoleh feedback bagi siswa. Teknik evaluasi ialah salah satu komponen penting dalam proses pembelajaran (Astuti, 2017), dan salah satu rangkaian kegiatan dalam meningkatkan kualitas, kinerja, atau produktivitas suatu lembaga pendidikan (Lottung Siregar Raja, 2017). Evaluasi proses belajar mengajar menyangkut penilaian terhadap kegiatan guru dan siswa, terutama penilaian hasil belajar jangka pendek dan panjang (Sudjana, 2009; Yulianti, 2016).

Oleh karena demikian, peneliti telah melakukan studi pendahuluan di beberapa sekolah di Kota dan Kabupaten Bima terhadap sistem pelaksanaan evaluasi pembelajaran dan ditemukan beberapa permasalahan yang dihadapi dengan mengandalkan pemanfaatan jaringan internet atau belajar secara daring, antara lain: 1) efektifitas evaluasi belum terlihat dengan baik dan pelaksanaan prinsip evaluasi pun tak terlihat; 2) lemahnya kompetensi guru dalam pemanfaatan aplikasi berbasis IT; 3) guru masih kebingungan memberikan dan menyimpulkan capaian siswa selama proses belajar; 4) instrumen evaluasi tak pernah diprioritaskan dan sekolah tidak memiliki plaform penilaian; 5) evaluasi hanya menggunakan item pelaksanaan di sekolah dan tidak memiliki arah; 6) evaluasi terkendala dengan Covid-19 yang akibat pada proses belajar tatap muka ditiadakan, dan 7) konektifitas antara guru, siswa, dan orang

tua dalam pembelajaran daring yang belum terkoneksi dengan baik.

Untuk itu, sektor pendidikan mengalami banyak hal tantangan yang perlu disesuaikan dengan kondisi hari ini. Dalam konteks pembelajaran di kelas, terutama proses evaluasi, penilaian dan pengukuran pun mesti dilakukan transformasi yang mampu mengarahkan pada citacita atau tujuan pendidikan nasional. Akan tetapi, dinamika pendidikan ialah salah satunya mesti melakukan penyesuaian evaluasi pembelajaran untuk penentuan standar kenaikan kelas dan kelulusan (Mansyur, 2020).

Untuk itu, bahwa sejak adanya wabah ini ada dan berefek terutama dunia pendidikan, telah banyak dilakukan penelitian oleh peneliti di Indonesia terutama tentang pembelajaran daring di era Covid-19, seperti implementasi pelaksanaan pembelajaran daring (Mustakim, 2020; Putria et al., 2020; Nurdin \& Anhusadar, 2020; Dwi et al., 2020; Sadikin \& Hamidah, 2020; Nurhayati, 2020; Malyana, 2020) dan dampak dari kebijakan pelaksanaan pembelajaran daring (Mansyur, 2020; Dewi, 2020; Wiresti, 2020; Mustafa, 2020; Owusu-Fordjour et al., 2020; Napitupulu, 2020) dan dengan kondisi yang sedang dihadapi mengharuskan guru untuk lebih inovatif (Ahmed et al., 2020; Arifa, 2020).

Berdasarkan hasil analisis peneliti bahwa penelitian tentang evaluasi pelaksanaan pembelajaran daring selama pandemi Covid-19 belum dilakukan secara komperhensif dan kritis dengan objek utamanya ialah guru, siswa, dan orang tua di sekolah baik tingkat SD/MI, SMP/MTs, SMA/MA/SMK oleh peneliti di 
181 Eksplorasi Sistem Pelaksanaan Evaluasi Pembelajaran di Sekolah pada Masa Pandemi Covid-19 di Bima - Muh. Fitrah, Ruslan

DOI: https://doi.org/10.31004/basicedu.v5i1.639

Indonesia. Dalam hal ini ialah pelaksanaan evaluasi pembelajaran secara umum dengan aspek kognitif, afektif, dan psikomotorik. Padahal evaluasi ialah domain yang harus ada dan penting diperhatikan dalam tatanan pelaksanaan kegiatan pembelajaran siswa selama proses belajar daring.

Salah satu penelitian yang telah dilakukan oleh peneliti di Indonesia dengan desain penelitian library research dengan sumber data dari buku, jurnal, karya ilmiah, dan juga dokumen-dokumen lain yakni Ahmad, (2020), menunjukkan bahwa ada beberapa model asesmen yang dapat diterapkan dalam proses pembelajaran jarak jauh, diantaranya ialah penilaian berbasis daring, penilaian portofolio, dan penilaian diri atau self asessment. Berdasarkan hasil penelitian tersebut, dapat dianalisa bahwa lebih fokus kepada desain dan model assesmen dan peneliti lebih condong memaknai konsep tanpa melihat dan mengidentifikasi kondisi dan situasi hari ini yakni Covid-19. Penelitian relevan yang dirujuk lebih dominan pada asesmen yang digunakan pada konteks pembelajaran tatap muka.

Oleh karena demikian, berangkat dari berbagai macam problem yang terjadi seperti uraian diatas dan hasil identifikasi hasil penelitian relevan, maka dalam hal ini ialah perlu diteliti eksplorasi sistem pelaksanaan evaluasi pembelajaran di sekolah pada masa pandemik Covid-19 di Kota Bima. Untuk itu, rumusan masalahnya ialah bagaimana sistem pelaksanaan evaluasi pembelajaran di sekolah pada masa pandemi Covid-19 di Bima beserta problem yang dihadapinya.

\section{METODE}

Penelitian ini menggunakan penelitian kualitatif yang bersifat eksploratif. Penelitian kualitatif secara umum ialah mendepankan narasi ilmiah sebagai bentuk eksplorasi hasil penelitian (Muh Fitrah, 2017). Dengan sumber data utamanya ialah guru mata pelajaran di SD/MI, MTs/SMP, dan SMA/MA/SMK di Kota dan Kabupaten Bima sebanyak 30 orang responden. Untuk lebih jelasnya dapat ditinjau dari tabel di bawah ini.

Tabel 1. Data Responden di Kota dan Kabupaten Bima

\begin{tabular}{lc}
\hline \multicolumn{1}{c}{ Sekolah } & Responden \\
\hline SD/MI & 10 Orang \\
SMP/MTs & 10 Orang \\
SMA/MA/SMK & 10 Orang \\
\hline
\end{tabular}

Pengumpulan data penelitian ini menggunakan metode wawancara langsung dan tak langsung beserta dokumentasi. Sehingga instrumen utama dalam penelitian ialah peneliti, dan dibantu dengan lembar wawancara dan kamera.

Tabel 2. Pedoman Wawancara

\begin{tabular}{|c|c|c|}
\hline $\begin{array}{l}\text { Subjek dan } \\
\text { Objek } \\
\text { Penelitian }\end{array}$ & & Pertanyaan \\
\hline \multirow{5}{*}{$\begin{array}{l}\text { Guru Mata } \\
\text { Pelajaran di } \\
\text { SD/MI, } \\
\text { SMP/MTs, } \\
\text { SMA/MA/SMK }\end{array}$} & 1) & $\begin{array}{l}\text { Apakah proses belajar di } \\
\text { sekolah dilakukan daring? }\end{array}$ \\
\hline & 2) & $\begin{array}{l}\text { Apakah dilakukan evaluasi } \\
\text { terhadap proses belajar } \\
\text { selama pandemi Covid-19? }\end{array}$ \\
\hline & 3) & $\begin{array}{l}\text { Bagaimana cara guru } \\
\text { melakukan evaluasi selama } \\
\text { pandemi Covid19? }\end{array}$ \\
\hline & 4) & $\begin{array}{l}\text { Apa saja alat atau instrumen } \\
\text { yang digunakan oleh guru } \\
\text { untuk melaksanakan } \\
\text { evaluasi? }\end{array}$ \\
\hline & & Alasan menggunakan alat \\
\hline
\end{tabular}




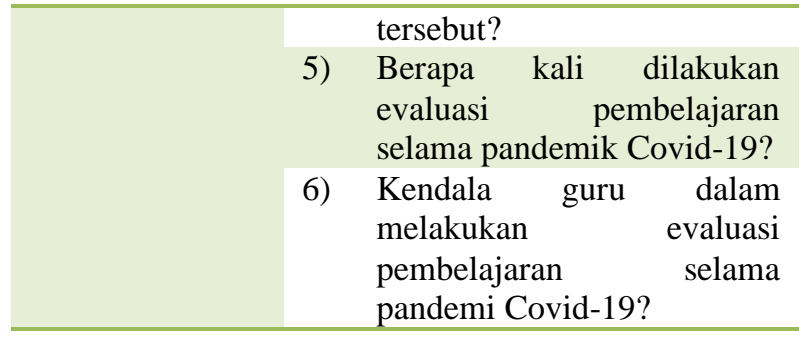

Kemudian teknik pengumpulan datanya dengan langkah pengumpulan data, reduksi data, penyajian data, dan penarikan kesimpulan sehingga analisis datanya dilakukan dengan analisis kualitatif deskriptif.

\section{HASIL DAN PEMBAHASAN}

Berdasarkan hasil wawancara yang telah dilakukan di sekolah dengan sumber datanya 30 orang responden, bahwa secara umum pelaksanaan pembelajaran selama masa pandemi Covid-19 dilakukan dengan tiga cara: 1) daring; 2) luring atau tatap muka dengan kelas shift, dan 3) kolaborasi antara daring dan luring. Oleh karena demikian, pelaksanaan evaluasi pembelajaran selama Covid-19 dilakukan sepenuhnya oleh guru mata pelajaran, baik yang melaksanakan pembelajaran secara daring, luring dan kolaborasi itu sendiri.

Berdasarkan data hasil penelitian tersebut, dapat disimpulkan bahwa sekolah di Bima (kota dan kabupaten) telah melakukan dan mengikuti arahan edaran Kemendikbud tentang pelaksanaan pembelajaran tatap muka ditiadakan sementara dan dilakukan secara daring. Lebih lanjut dari hasil wawancara yang diperoleh dan dapat dieksplorasi tentang sistem pelaksanaan evaluasi pembelajaran di sekolah SD/MI, SMP/MTs, dan SMA/MA/SMK selama pandemi Covid19, antara lain dapat disimpulkan:

\begin{abstract}
Pelaksanaan evaluasi di sekolah selama masa pandemi Covid-19 dalam bentuk soal uraian. Soalnya kami foto terlebih dahulu dan kirim ke WA grup orang tua siswa dalam bentuk gambar. Siswa biasanya mengerjakan soal langsung dibimbing oleh orang tuanya atau kakaknya. Tetapi untuk membuktikan bahwa siswa kerja sendiri atau tidak, kami meminta untuk dibuatkan video pengerjaan siswa secara langsung. Kemudian bentuk lainnya juga di sekolah, perbanyak LKS yang dikirim langsung ke rumah siswa dengan proses belajar visit home karena di sekitar itu dibentuk kelompok belajar 3-5 orang satu lingkungan. Model lain pelaksanaan evaluasi dilaksanakan dengan menggunakan aplikasi Zoom Meeting saat pembelajaran berlangsung.
\end{abstract}

Berdasarkan data tersebut dapat digambarkan bahwa secara umum sekolah melaksanakan evaluasi pembelajaran ini dominan menggunakan aplikasi WhatsApp sebagai sarana utama penyampaian soal-soal ujian, ulangan, dan latihan. Serta ada pula yang menggunakan aplikasi Zoom Meeting tetapi hanya beberapa sekolah, dikarenakan skill guru mata pelajaran itu sendiri. Sedangkan waktu pelaksanaannya evaluasi pembelajaran di masa pandemi ini berdasarkan wawancara, dapat digambarkan bahwa:

\begin{abstract}
Kegiatan evaluasi selama pandemi covid19 dilakukan dalam seminggu itu rutin dan mengutamakan pengayaan dan didampingi langsung oleh orang tuanya. Bahkan ada pula guru yang hanya melakukan sekali dalam sebulan, berhubungan dengan kuota dan keluhan orang tua siswa.
\end{abstract}

Berdasarkan hasil wawancara tersebut, menunjukkan bahwa guru di sekolah sekedar melaksanakan evaluasi sebagai bentuk pengurangan pelaksanaan sebagai guru. Tidak memiliki arah dan indikator yang semestinya 
183 Eksplorasi Sistem Pelaksanaan Evaluasi Pembelajaran di Sekolah pada Masa Pandemi Covid-19 di Bima - Muh. Fitrah, Ruslan

DOI: https://doi.org/10.31004/basicedu.v5i1.639

terlebih lagi pada aspek kognitif, afektif, dan psikomotorik. Sedangkan untuk kendala pelaksanaan evaluasi proses pembelajaran di masa pandemi Covid-19 ini banyak hal, antara lain yang diperoleh dari hasil wawancara:

Antusias atau minat siswa dalam menyelesaikan soal secara online rendah, tingkat pasrtisipasi siswa dalam proses pembelajaran lemah dikarenakan siswa tidak terlibat dalam kelas online, jam belajar kurang, skill orang tua, guru, dan siswa dalam teknologi lemah, pemanfaatan aplikasi terbatas, nilai akhir hanya fokus pada proses penilaian dan jawaban soal semata, jaringan internet lemah dan atau kuota terbatas (hanya mengandalkan bantuan pemerintah), dominan siswa dan orang yang tidak memiliki HP, guru tidak dapat terlibat secara langsung memastikan siswa menyelesaikan masalah, tidak memiliki acuan dalam proses penilaian online seperti penilaian aspek afektif, membutuhkan waktu yang cukup lama, guru kebingungan memilih instrumen yang tepat dan model soal yang ingin digunakan, jaringan internet tak dijangkau (pedalaman), siswa tidak memiliki sumber belajar yang mendukung untuk memastikan pemahaman dan menyelesaikan masalah yang diberikan oleh guru, dan ruang dan waktu terbatas untuk menjelaskan proses penyelesaian yang semestinya.

Berdasarkan uraian tersebut, dapat disimpulkan bahwa pelaksanaan evaluasi selama masa pandemi ini tidaklah efektif dan sesuai dengan acuan, aturan dan pedoman seperti biasanya, baik aspek kognitif, afektif, dan psikomotorik.

Evaluasi pembelajaran di masa pandemi ini, guru dibatasi dengan kemampuan dan keterampilan pemanfaatan teknologi yang dipilih sebagai aplikasi atau fitur belajar daring sehingga evaluasi dilakukan apanya dan tidak menerapkan prinsip-prinsip evaluasi secara umum. Bahkan adanya pembatalan proses penilaian keterampilan siswa (Syah, 2020). Hal sederhana yang diabaikan oleh guru dalam belajar daring ialah dalam proses evaluasi tidak diterapkannya prinsip evaluasi seperti objektif, adil, dan mendidik. Seirama dengan hasil penelitian Mustakim (2020) yang diperoleh dari saran siswa tentang efektifitas belajar daring yakni pemberian soal yang bervariatif dan berbeda tiap siswa.

Dalam konteks ini bahwa guru memberikan apresiasi kepada siswa dengan keterlibatan aktif saja di saat belajar online dan tidak didasari dari kemampuan kognitif, afektif, dan psikomotorik itu sendiri. Ada kerugian bagi siswa ketika proses belajar di kelas tatap muka ditiadakan. Ujian yang mestinya dilakukan oleh siswa pada kondisi normal, sekarang dengan adanya Covid-19, tes dan non tes ditunda prosesnya.

Beberapa yang menganggap hilangnya informasi evaluasi siswa sangatlah berarti bagi keberlangsungan masa depan siswa. Misalkan saja target-target keterampilan, proses dan pengetahuan (aspek kognitif, afektif, dan psikomotorik) tertentu siswa yang mestinya tahun ini mendapatkan evaluasi sehingga berefek untuk tahun-tahun yang akan datang.

Dalam hal ini yang dapat dilakukan oleh guru ialah pemberian tugas melalui grup WhatsApp dan dibuktikan dokumen berupa video penyelesaian atas soal-soal yang diberikan. Hasil Rosali et al., (2020) bahwa WhatsApp dirasakan paling praktis dan minim kuota dibandingkan aplikasi lainnya. Dari hal itu, tentu guru perlu memastikan bahwa soal tidak melebar dan benarbenar dengan konten materi yang ada pada buku digital atau buku pegangan siswa. Guru dapat memantau proses belajar salah satunya ialah 
184 Eksplorasi Sistem Pelaksanaan Evaluasi Pembelajaran di Sekolah pada Masa Pandemi Covid-19 di Bima - Muh. Fitrah, Ruslan

DOI: https://doi.org/10.31004/basicedu.v5i1.639

mengerjakan soal dengan proses pemantau lewat video call dengan orang tua dan soal harus sesuai dengan buku pegangan siswa (W. A. F. Dewi, 2020).

Oleh karena demikian, yang terpenting juga ialah perlu memastikan adanya kerja sama antara siswa dengan guru, guru dengan orang tua, dan orang tua dengan siswa. Sehingga akan terjadi proses yang berkelanjutan beserta hasil yang memuaskan satu dengan yang lainnya. Implementasi pembelajaran daring dapat berjalan dengan baik terutama konteksnya adalah proses penilaian, maka sesungguhnya mesti ada kolaborasi nyata antara guru, siswa, dan orang tua (Ali \& Murdiana, 2020; Rasmitadila et al., 2020; Dewi, 2020), sehingga dari aktivitas demikian akan membuat orang tua dan anak semakin kompak (M. S. Dewi, 2019).

Terlepas dari hal demikian, berdasarkan hasil dan penjelasan sebelumnya bahwa beragam kendala guru dalam proses pelaksanaan evaluasi ini, seperti kesulitan dalam mengidentifikasi kemampuan siswa, pemilihan soal, kontinuitas pelaksanaan, dan efektifitas media daring, maka sekolah perlu memastikan guru siap memanfaatkan sekian banyak fitur online untuk menunjang pelaksanaan evaluasi pembelajaran daring. Fiturfitur online tidak hanya WhatsApp dan Zoom Meeting, akan tetapi sangatlah beragam yang dapat dimanfaatkan oleh guru di sekolah maupun di rumah seperti Etmodo, Moodle, dan lainnya. Hasil penelitian Mansyur (2020) bahwa transformasi media pembelajaran berbasis teknologi melalui penggunaan WhatsApp Group, Zoom, Google Classroom, WebEx, Youtube, dan saluran TV
(TVRI), diperlukan tindaklanjut oleh sekolah maupun guru dalam memastikan platform online ke siswa dengan maksimal (Owusu-Fordjour et al., 2020).

Kemudian untuk menunjang kompetensi guru, sekolah perlu melakukan koordinasi dan bekerjasama dengan perguruan tinggi di bidang teknologi pembelajaran dan pendidikan, melakukan pembinaan dan penguatan keterampilan teknologi secara kontinu, mengefektifkan Kelompok Kerja Guru (KKG) mata pelajaran untuk menjadi wadah sharing ruang dan gagasan guru dengan memperhatikan protokol kesehatan di masa pandemi ini dan tentunya ialah pengembangan pembelajaran di sekolah secara online. Hasil penelitian yang dikemukakan oleh Guntoro (2020) tentang kepemimpinan kepala sekolah, bahwa di masa bekerja dari rumah perlu model kerja yang dibutuhkan masa kekinian dan yang mampu beradaptasi dengan kondisi saat ini, seperti adanya peran kepemimpinan digital dan lingkungan kerja digital.

\section{SIMPULAN}

Berdasarkan hasil dan pembahasan, maka dalam penelitian ini dapat disimpulkan bahwa sistem pelaksanaan evaluasi pembelajaran selama pandemi Covid-19 dilaksanakan sesuai dengan kesiapan dan kemampuan guru di era teknologi dan belum mengarahkan pada output yang jelas. Terlepas dari hal demikian, untuk aspek kognitif, afektif, dan psikomotirik pun tidak efektif dilaksanakan dan hanya sebagai bentuk laporan pertanggungjawaban guru ke sekolah, siswa, dan orang tua tanpa memiliki arah. Guru di sekolah 
secara umum menggunakan aplikasi WhatsApp sebagai sarana penyampaian soal, latihan, dan ulangan bahkan ada pula yang menggunakan aplikasi Zoom Meeting. Soal-soal lebih fokus ke uraian dan esai yang di foto, video, dan dikirimkan ke grup WhatsApp kelas dan orang tua.

Sedangkan selama melaksanakan evaluasi pembelajaran di masa pandemi Covid-19 ini guru dihadapkan beragam masalah, antara lain: desain instrumen masih dirasa kebingungan oleh guru, partisipasi siswa rendah, keaktifan siswa lemah, pemahaman siswa terhadap soal kurang, soal tanpa penjelasan, kuota internet lemah, skill guru, siswa, dan orang tua lemah, dan lainnya. Oleh karena demikian, perlu pelatihan secara secara kontinu dalam mendesain evaluasi pembelajaran masa pandemi atau pembelajaran daring, harus melakukan konektivitas atau kerja sama dengan perguruan tinggi sebagai mitra penyusunan model evaluasi, dan butuh keuletan, kesabaran guru dalam memastikan pencapaian siswa dari aspek kognitif, afektif, dan psikomotorik.

\section{DAFTAR PUSTAKA}

Abidah, A., Hidaayatullaah, H. N., Simamora, R. M., Fehabutar, D., \& Mutakinati, L. (2020). The Impact Of Covid-19 To Indonesian Education And Its Relation To The Philosophy Of "Merdeka Belajar." Studies In Philosophy Of Science And Education. Https://Doi.Org/10.46627/Sipose.V1i1.9

Ahmad, I. F. (2020). Alternative Assessment In Distance Learning In Emergencies Spread Of Coronavirus Disease ( Covid-19). Jurnal Pedagogik.

Ahmad, Perwira Negara, H. R., Ibrahim, M., \& Etmy, D. (2020). Pelatihan Pembelajaran Daring (Google Classroom) Bagi Guru Mts Dan MI Nurul Yaqin Kelanjur. JPMB :
Jurnal Pemberdayaan Masyarakat Berkarakter. Https://Doi.Org/10.36765/Jpmb.V3i1.224

Ahmed, S., Shehata, M., \& Hassanien, M. (2020). Emerging Faculty Needs For Enhancing Student Engagement On A Virtual Platform. Mededpublish.

Https://Doi.Org/10.15694/Mep.2020.000075. 1

Ali, Z. Z., \& Murdiana, E. (2020). Peran Dan Fungsi Keluarga Dalam Pendampingan Pendidikan Anak Ditengah Pandemi Covid19. JSGA: Jurnal Studi Gender Dan Anak.

Arifa, F. N. (2020). Tantangan Pelaksanaan Kebijakan Belajar Dari Rumah Dalam Masa Darurat Covid-19. Info Singkat;Kajian Singkat Terhadap Isu Aktual Dan Strategis.

Astuti, E. T. (2017). Problematika Implementasi Penilaian Autentik Kurikulum 2013 Dalam Pembelajaran Pendidikan Agama Islam Di Sd Negeri Ploso I Pacitan. Al-Idaroh.

Dewi, M. S. (2019). Respon Orang Tua Terhadap Pembelajaran Daring Pada Masa Pandemi Covid-19. THUFULI: Jurnal Ilmiah Pendidikan Islam Anak Usia Dini.

Dewi, W. A. F. (2020). Dampak COVID-19 Terhadap Implementasi Pembelajaran Daring Di Sekolah Dasar. EDUKATIF : JURNAL ILMU PENDIDIKAN. Https://Doi.Org/10.31004/Edukatif.V2i1.89

Dwi, B., Amelia, A., Hasanah, U., \& Putra, A. M. (2020). Analisis Keefektifan Pembelajaran Online Di Masa Pandemi Covid-19. In Jurnal Pendidikan Guru Sekolah Dasar.

Firman, Rahayu, S., Aji, W., Dewi, F., Kristen, U., Wacana, S., Abidin, Z., Arizona, K., Barat, N. T., Studi, P. P. C.-, Fisika, T., Arthamin, M. Z., Batubara, Hamdan, H., Ariani, D. N., Tengah, D., Pandemi, W., Learning, S. D., Pujilestari, Y., Abidin, Z., ... Anhusadar, L. O. (2020). Platform Whatsapp Group Dan Webinar Zoom Dalam Pembelajaran Jarak Jauh Pada Masa Pandemik Covid 19. Jurnal Ilmiah Pendidikan Matematika Volume.

GTPP Covid-19. (2020). Pedoman Penanganan Cepat Medis Dan Kesehatan Masyarakat Covid-19 Di Indonesia. In 23 Maret. 
Guntoro, M. (2020). Transformasi Kepemimpinan Adaptif Di Tengah Pandemi Covid-19. CENDEKIA Jaya.

Indrawati, B. (2020). Tantangan Dan Peluang Pendidikan Tinggi Dalam Masa Dan Pasca Pandemi Covid-19. Jurnal Kajian Ilmiah. Https://Doi.Org/10.31599/Jki.V1i1.261

Kemdikbud, Pengelola Web. (2020). Kemendikbud Terbitkan Pedoman Penyelenggaraan Belajar Dari Rumah. Jakarta, 28 Mei 2020.

Lottung Siregar Raja. (2017). Evaluasi Hasil Belajar Pendidikan Islam. HIKMAH: Jurnal Pendidikan Islam, 6(1).

Malyana, A. (2020). Pelaksanaan Pembelajaran Daring Dan Luring Dengan Metode Bimbingan Berkelanjutan Pada Guru Sekolah Dasar Di Teluk Betung Utara Bandar Lampung. Jurnal Ilmiah Pendidikan Dasar Indonesia.

Mansyur, A. R. (2020). Dampak COVID-19 Terhadap Dinamika Pembelajaran Di Indonesia. Education And Learning Journal. Https://Doi.Org/10.33096/Eljour.V1i2.55

Muh Fitrah, L. (2017). Metodologi Penelitian; Penelitian Kualitatif, Tindakan Kelas \& Studi Kasus. Jejak Publisher.

Mustafa, N. (2020). Impact Of The 2019-20 Coronavirus Pandemic On Education. International Journal Of Health Preferences Research.

Mustakim. (2020). Efektivitas Pembelajaran Daring Menggunakan Media Online Selama Pandemi Covid-19 Pada Mata Pelajaran Matematika. Journal Of Islamic Education.

Napitupulu, R. M. (2020). Dampak Pandemi Covid-19 Terhadap Kepuasan Pembelajaran Jarak Jauh. Jurnal Inovasi Tekonologi Pendidikan.

Nurdin, N., \& Anhusadar, L. (2020). Efektivitas Pembelajaran Online Pendidik PAUD Di Tengah Pandemi Covid 19. Jurnal Obsesi : Jurnal Pendidikan Anak Usia Dini. Https://Doi.Org/10.31004/Obsesi.V5i1.699

Nurhayati, E. (2020). Meningkatkan Keaktifan Siswa Dalam Pembelajaran Daring Melalui Media Game Edukasi Quiziz Pada Masa
Pencegahan Penyebaran Covid-19. Jurnal Paedagogy.

Nurkholis. (2020). Dampak Pandemi NovelCorona Virus Disiase ( Covid-19) Terhadap Psikologi Dan Pendidikan Serta Kebijakan Pemerintah. Pgsd.

Owusu-Fordjour, C., Koomson, C. K., \& \& Hanson, D. (2020). The Impact Of COVID19 On Learning-The Perspective Of The Ghanaian Student. European Journal of Education Studies.

Purwanto, A., Pramono, R., Asbari, M., Santoso, P. B., Wijayanti, L. M., Choi, C. H., \& Putri, R. S. (2020). Studi Eksploratif Dampak Pandemi COVID-19 Terhadap Proses Pembelajaran Online Di Sekolah Dasar. Edupsycouns: Journal Of Education, Psychology And Counseling.

Putria, H., Maula, L. H., \& Uswatun, D. A. (2020). Analisis Proses Pembelajaran Dalam Jaringan (DARING) Masa Pandemi COVID19 Pada Guru Sekolah Dasar. Jurnal Basicedu.

Rasmitadila, Aliyyah, R. R., Rachmadtullah, R., Samsudin, A., Syaodih, E., Nurtanto, M., \& Tambunan, A. R. S. (2020). The Perceptions Of Primary School Teachers Of Online Learning During The Covid-19 Pandemic Period: A Case Study In Indonesia. Journal Of Ethnic And Cultural Studies. Https://Doi.Org/10.29333/Ejecs/388

Rosali, E. S., Pendidikan, J., \& Universitas, G. (2020). Aktifitas Pembelajaran Daring Pada Masa Pandemi Covid-19 Di Jurusan Pendidikan Geografi Universitas Siliwangi Tasikmalaya. Geography Science Education Journal (GEOSEE.

Sadikin, A., \& Hamidah, A. (2020). Pembelajaran Daring Di Tengah Wabah Covid-19 ( Online Learning In The Middle Of The Covid-19 Pandemic ). BIODIK: Jurnal Ilmiah Pendidikan Biologi.

Sari, M., Darmawan, H., PGRI Pontianak Prodi Pendidikan Biologi, I., MIPA Dan Teknologi, F., \& Ampera No, J. (2020). Analisis Pembelajaran Di Era Pandemik (Covid-19) Pada Program Studi Pendidikan Biologi Ikip Pgri Pontianak. Jptik. 
187 Eksplorasi Sistem Pelaksanaan Evaluasi Pembelajaran di Sekolah pada Masa Pandemi Covid-19 di Bima - Muh. Fitrah, Ruslan

DOI: https://doi.org/10.31004/basicedu.v5i1.639

Siahaan, M. (2020). Dampak Pandemi Covid-19 Terhadap Dunia Pendidikan. Jurnal Kajian Ilmiah.

Https://Doi.Org/10.31599/Jki.V1i1.265

Sudjana, N. (2009). Penilaian Hasil Proses Belajar Mengajar. In Sinarbaru.

Suteki. (2020). 7 Dampak Positif Pandemi Covid19 Bagi Dunia Pendidikan. SUTEKI TECHNOLOGY.

Syah, R. H. (2020). Dampak Covid-19 Pada Pendidikan Di Indonesia: Sekolah, Keterampilan, Dan Proses Pembelajaran. SALAM: Jurnal Sosial Dan Budaya Syar-I. Https://Doi.Org/10.15408/Sjsbs.V7i5.15314

Wekke Ismail, S. A. (2020). Pembelajaran Di Masa Pandemi: Tidak Hanya Metode Daring Saja. OSF PREPRINTS. Https://Doi.Org/Https://Doi.Org/10.31219/Os f.Io/Njtku

Wiresti, R. D. (2020). Analisis Dampak Work From Home Pada Anak Usia Dini Di Masa Pandemi Covid-19. Jurnal Obsesi : Jurnal Pendidikan Anak Usia Dini. Https://Doi.Org/10.31004/Obsesi.V5i1.563

Yulianti, Y. (2016). Pengembangan Alat Evaluasi Hasil Belajar Mata Pelajaran Pendidikan Agama Islam Berbasis Taksonomi Bloom Dua Dimensi. JOIES: Journal Of Islamic Education Studies.

Yulianto Yulianto, D. (2020). Pengaruh Pembelajaran Daring Pengguna Platform Digital Terhadap Pemecahan Masalah Matematis Dan Sikap Kritis Siswa Di Ma Daar El Qolam. Symmetry: Pasundan Journal of Research in Mathematics Learning and Education. https://doi.org/10.23969/symmetry.v5i1.2790 